\title{
The Sulphur Metabolism of Pityrosporum ovale and its Inhibition by Selenium Compounds
}

\author{
By JANET BROTHERTON \\ Unilever Research Laboratory, London Road, Isleworth, Middlesex \\ (Accepted for publication 5 June 1967) \\ SUMMARY
}

A medium was developed for the more rapid culture of Pityrosporum ovale. $\left[{ }^{35} \mathrm{~S}\right]$ Methionine was utilized preferentially as sole sulphur source from which cysteine/cystine were synthesized. Growth was less on cysteine, negligible on cystine and nil on inorganic sulphite and sulphate. Selenium disulphide, amorphous sulphur, stable colloidal (red) selenium and selenourea were extremely toxic, entering the organism by diffusion. Tellurium and selenomethionine entered the organism, the latter by active transport, but were not toxic for up to I week of incubation although synthesis of $\left[{ }^{75} \mathrm{Se}\right]$ selenomethionine was demonstrated. Selenite and metallic (black) selenium were not toxic and did not enter the organism. Possible mechanisms of toxicity are discussed.

\section{INTRODUCTION}

Schultz \& McManus (1950) measured the growth of 80 strains of yeast with sulphate, cystine, methionine or glutathione as sole sulphur source in a defined medium and divided the strains into classes: (i) those which utilized methionine and cystine and (ii) those which utilized methionine but not cystine. One strain was found which utilized all the compounds tested except sulphate equally. Margolis \& Block (1958) measured the relative growth of one strain from each class on 30 sulphur compounds and found that most of those yeasts which did not utilize cystine did utilize cysteine. Skerman \& Singleton (1964) reported another strain of yeast which did not use inorganic sulphate although full growth was obtained with cysteine or methionine, and $85 \%$ growth with cystine. This yeast was a strain of Debaromyces kloeckeri, an inhabitant of sub-Antarctic soil rich in organic sulphur compounds.

Wood \& Perkinson (1952) grew yeasts on $\mathrm{Na}_{2}{ }^{35} \mathrm{SO}_{4}$ and found most of the activity in the methionine and cystine of the cell-wall protein, with a small portion in the cysteine as part of the cytoplasmic glutathione. In similar experiments a very small degree of activity was reported also in biotin, thiamin, coenzyme $\mathrm{A}$ and $S$-adenosylmethionine (Maw, 1963; Pigg, Spence \& Parks, 1962). This paper describes the sulphur metabolism of Pityrosporum ovale, a lipophilic yeast which is found on human scalps, usually associated with dandruff (Spoor, Traub \& Bell, I954), and its growth inhibition by certain sulphur and selenium compounds. 


\section{Growth conditions}

\section{METHODS}

Pityrosporum ovale $9265 / 3$, originally isolated in this laboratory from a human scalp, was indistinguishable morphologically and biochemically from type cultures 3073 and 3074 (London School of Hygiene and Tropical Medicine) and I878, 4163, 5332, 5333 and 5334 (Centraalbureau voor Schimmelcultures, Delft). This organism was maintained on Littman ox-gall agar slopes (Oxoid). Subculture into Littman oxgall broth at $37^{\circ}$ gave luxuriant growth in shake culture. Organisms were washed in Ringer solution and an even suspension prepared in a Jencon homogenizer. The suspension was adjusted to give $50 \%$ transmission in an EEL absorptiometer, diluted 100 times and $0.1 \mathrm{ml}$. added as inoculum to media.

Cultures can be maintained in a defined medium containing a fatty acid, asparagine and oxaloacetate, yielding about $3 \mathrm{mg}$. dry wt organisms $/ \mathrm{ml}$. in 4-6 weeks (Benham, 194I, 1945). Much better growth was obtained in the present work in a medium containing: $2 \mathrm{mg}$. palmitic acid, $8 \mathrm{ml}$. $0.0224 \mathrm{M}-\mathrm{NH}_{4} \mathrm{Cl}, \mathrm{I} 5 \mathrm{ml}$. of the salts solution and $2 \mathrm{ml}$. of the growth factor solution of Schultz \& McManus (I950), 0.2 ml. of the trace element solution of Skerman \& Singleton (1964), $3 \mathrm{ml}$. phosphate buffer ( $\mathrm{pH} 5 \cdot 0$; Schultz, McManus \& Pomber, I949), I ml. of an aqueous solution of sulphur source (as below); total volume $\mathrm{I} 9 \cdot 2 \mathrm{ml}$., $\mathrm{pH} 5 \cdot 0$. To this was added I g. egg-yolk lecithin (95-100\% pure, British Drug Houses Ltd.) or $5 \mathrm{ml}$. of $6 \%(\mathrm{w} / \mathrm{v})$ aqueous solution of sodium taurocholate (67\% pure, Difco Laboratories) which served to emulsify the palmitic acid and to provide other unidentified water-soluble growth factors. Compounds for testing as sole sulphur source were prepared in water, with the addition of $\mathrm{HCl}$ when necessary (e.g. for cystine) at a concentration of I mg. S/ml. and sterilized by filtration (Postgate, 1963).

For estimation of amounts of growth, organisms were harvested after 3 days in shake culture at $37^{\circ}$, washed three times with $10 \mathrm{ml} .0 .9 \%(\mathrm{w} / \mathrm{v}) \mathrm{NaCl}$ solution, three times with $10 \mathrm{ml}$. water and stood twice in $10 \mathrm{ml}$. chloroform + methanol + conc. $\mathrm{HCl}$ $\left(50+50+\mathrm{I}\right.$, by vol.) for $\mathrm{I} \mathrm{hr}$ at $25^{\circ}$ to remove external lipid. The organisms were then suspended in a minimum of chloroform + methanol $(I+I, v / v)$ and dried to constant weight.

\section{Metabolism of ${ }^{35} \mathrm{~S}$ - and ${ }^{75}$ Se-amino acids}

$\left.{ }^{[55} \mathrm{S}\right] \mathrm{L}$-cystine $.2 \mathrm{HCl}, \quad\left[{ }^{35} \mathrm{~S}\right] \mathrm{L}$-cysteine. $\mathrm{HCl}, \quad\left[{ }^{35} \mathrm{~S}\right] \mathrm{L}$-methionine, $\quad\left[{ }^{75} \mathrm{Se}\right] \mathrm{L}$-selenomethionine and $\mathrm{Na}_{2}{ }^{35} \mathrm{SO}_{4}$ (carrier free) were obtained from the Radiochemical Centre, Amersham, Buckinghamshire, England, and sterilized by filtration except the sulphate which was heated at $100^{\circ}$ for Io min. (Pasternak, I962). One ml. of a solution containing $30-40 \mu \mathrm{C}$ of ${ }^{35} \mathrm{~S}$ or ${ }^{75} \mathrm{Se}$ compound together with $50 \mu \mathrm{g}$. of inactive compound was added to the growth medium as sole sulphur source.

Organisms were harvested after incubation at $37^{\circ}$ for $24-48 \mathrm{hr}$ in shake-culture and washed three times with Io $\mathrm{ml} .0 .9 \%(\mathrm{w} / \mathrm{v}) \mathrm{NaCl}$, three times with $5 \mathrm{ml}$. I $\% \mathrm{~K}_{2} \mathrm{CO}_{3}$ to remove adherent fatty acids and three times with $5 \mathrm{ml}$. water. The removal of all extracellular ${ }^{35} \mathrm{~S}$ was checked by counting a portion of each type of pooled washings in an end-window counter. The washed organisms were disintegrated in a Mickle homogenizer, because of their very thick cell walls (Swift \& Dunbar, I965), made to $5^{\circ} 0 \mathrm{ml}$. and ${ }^{35} \mathrm{~S}$ counted in a $0.5 \mathrm{ml}$. portion of the suspension. For direct comparison of the 
uptake of $\beta$-[ $\left.{ }^{35} \mathrm{~S}\right]$ methionine and $\gamma$-[75Se]seleno-methionine, $0.5 \mathrm{ml}$. samples of the suspension were stood at $25^{\circ}$ for $\mathrm{I} 2 \mathrm{hr}$ with $\mathrm{O} . \mathrm{I} \mathrm{ml}$. M-hyamine hydroxide in methanol, $10 \mathrm{ml}$. scintillant added (4 g. BBOT (Ciba) in $500 \mathrm{ml}$. toluene $+500 \mathrm{ml}$. methanol) and the activity counted in an IDL liquid-scintillation counter. An internal standard in $0 . \mathrm{I} \mathrm{ml}$. methanol was added and the solution counted again to allow calculation of the efficiencies of counting.

For thin-layer chromatography of incorporated radioactive amino acids, the remaining suspension of washed organisms was oxidized with I $\mathrm{ml}$. formic acid $+30 \%$ $(\mathrm{w} / \mathrm{v}) \mathrm{H}_{2} \mathrm{O}_{2}(9+\mathrm{I}, \mathrm{v} / \mathrm{v})$ for $\mathrm{I} h \mathrm{hr}$ at $25^{\circ}$ (Eastoe \& Courts, I963). The reagent was removed by freeze drying, I $\mathrm{ml} .6 \mathrm{~N}-\mathrm{HCl}$ added and proteins hydrolysed in vacuum in a sealed tube at $100^{\circ}$ for $24 \mathrm{hr}$ (Crestfield, Moore \& Stein, 1963). The hydrolysates were freeze-dried, the residue dissolved in a minimum of $10 \%(\mathrm{v} / \mathrm{v})$ isopropanol in water and examined by thin-layer chromatography on Silica Gel G (Merck), with $n$-propanol $+34 \%(\mathrm{w} / \mathrm{v})$ ammonia $(70+30, \mathrm{v} / \mathrm{v})$ for one-dimensional chromatography (James \& Morris, 1964). For two-dimensional separation $n$-butanol+acetic acid +water $(4+4+\mathrm{I}$, by vol.) was followed by chloroform + methanol $+17 \%(\mathrm{w} / \mathrm{v})$ ammonia $(2+2+1$, by vol.). Amino acids were located with ninhydrin and autoradiography was done by using Kodak 0.800 Super-Speed orthochromatic plates for at least 5 days, development being with Ilford PQ Universal Developer and fixing with 'Amfix' (May and Baker Ltd., Dagenham, Essex, England).

Addition of inhibitors. Selenious acid, sodium selenite, DL-seleno-methionine (Calbiochem Ltd.) and seleno-urea were added as aqueous solutions. Selenium disulphide (British Drug Houses Ltd.) was deposited inside the culture flasks from a fresh solution in hexane (Io $\mu \mathrm{g}$. $/ \mathrm{ml}$.), the solvent being evaporated off; amorphous sulphur was similarly deposited in culture flasks as a solution of flowers of sulphur in $\mathrm{CS}_{2}$ (Horsfall, I956). An attempt was made to deposit red amorphous selenium, which exists in the same puckered rings of 8 atoms as amorphous sulphur, into flasks in a similar manner; but black crystalline 'metallic' selenium (British Drug Houses Ltd.), which exists in regular spirals of atoms, was insufficiently soluble in $\mathrm{CS}_{2}$, chloroform or ether. Red amorphous selenium was eventually prepared by dissolving selenious acid in water and adding $\mathrm{N}-\mathrm{SnCl}_{2}$ solution (I I $5 \mathrm{~g}$. $\mathrm{SnCl}_{2} 2 \mathrm{H}_{2} \mathrm{O}$ in $170 \mathrm{ml}$. I $2 \mathrm{~N}-\mathrm{HCl}$ made to I 1. with water; Treadwell \& Hall, 1952). The precipitate was washed with water and suspended in ethanol but, when placed in the growth medium, it rapidly reverted to the black allotrope. Elemental tellurium, which has no allotropic forms and exists as hexagonal rhombohedra isomorphous with rhombohedral sulphur, was added to the medium as an even suspension in benzene.

\section{RESULTS}

Maximum growth (6 mg. dry wt organism/19.2 ml. medium) was found with methionine and thiazolidine-4-carboxylic acid as sole sulphur sources. Less growth was found with cysteine $(4 \mathrm{mg}$.), methione sulphoxide $(3.5 \mathrm{mg}$.) $S$-methylcysteine (3 mg.) and cystine $(2.5 \mathrm{mg}$.). Growth was slight with homocysteine (I $\mathrm{mg}$.) or homocystine (I mg.). There was no growth with sulphate, sulphite or taurine and in the control without sulphur source. The preference for methionine, cysteine and cystine, in that order, was confirmed by measurement of the uptake of the $\left[{ }^{35} \mathrm{~S}\right]$ amino acids (Table I). Most amino acids are believed to be taken into the micro-organisms 
by active transport although differences in findings with different organisms raises the possibility that more than a single mechanism may be found to operate (Holden, I962). Autoradiography of cell hydrolysates showed the metabolism of methionine to cysteic acid and of cysteine to methionine sulphoxide. Very little metabolism of incorporated cystine occurred. Pityrosporum ovale is thus the third yeast to be recognized as unable to utilize inorganic sulphate. It is similar to the strain of Debaromyces kloeckeri from sub-Antarctic soil in that its natural habitat is rich in organic sulphur compounds. Pityrosporum ovale is thus in the class of yeasts defined by Schultz \& McManus (1950) as able to synthesize cystine from methionine but not the reverse, its ability to utilize cysteine agreeing with the findings of Margolis \& Block (I958) that most of the yeasts in this class can do so.

\section{Table 1 . Uptake of $\left[{ }^{35}\right.$ S]-amino acids by different strains of Pityrosporum ovale}

Organism grown in $19.2 \mathrm{ml}$. standard medium in shake culture at $37^{\circ}$ for 3 days (amounts of amino acids expressed as $\mu \mathrm{g}$. sulphur/culture).

\begin{tabular}{|c|c|c|c|c|c|c|}
\hline \multirow{2}{*}{$\begin{array}{l}\text { Sole sulphur } \\
\text { compound added } \\
\text { to medium }\end{array}$} & \multirow{2}{*}{$\begin{array}{l}\text { Sulphur } \\
\text { content } \\
\text { of medium at } \\
\text { at start }(\mu \mathrm{g} .)\end{array}$} & \multicolumn{5}{|c|}{ Strains } \\
\hline & & $9265 / 3^{*}$ & $\begin{array}{c}3073 \dagger \\
\text { Sul }\end{array}$ & $\begin{array}{l}3974 \dagger \\
\text { hur tak }\end{array}$ & $\begin{array}{c}\text { I } 878 \ddagger \\
\text { up }(\mu \mathrm{g} .)\end{array}$ & $4162_{+}^{+}$ \\
\hline Methionine & $10 \cdot 0$ & $4 \cdot 6$ & $3 \cdot 1$ & $2 \cdot 6$ & $2 \cdot 4$ & $1 \cdot 7$ \\
\hline Cysteine & $10 \cdot 0$ & $1 \cdot 7$ & $1 \cdot 3$ & 0.6 & $2 \cdot 4$ & $1 \cdot 7$ \\
\hline Cystine & $2 \cdot 4$ & 0.2 & $0 \cdot I$ & 0.2 & $I \cdot I$ & $0 \cdot 8$ \\
\hline
\end{tabular}

Selenium disulphide. Selenium disulphide is a potent fungicide (Nordlander, 1929) and has been incorporated into anti-dandruff shampoos for this reason (Thorne, 1963). The yield of Pityrosporum ovale grown with methionine as sole sulphur source and the uptake of $\left[{ }^{35} \mathrm{~S}\right]$-methionine were very sharply inhibited, i.e. an 'all-or-nothing' effect, when $\mathrm{SeS}_{2}$ was added to the medium. The concentration of $\mathrm{SeS}_{2}$ at which this cut-off occurred varied in the region of $10-20 \mu \mathrm{g}$. SeS $/ 19 \cdot 2 \mathrm{ml}$. medium, depending on very slight differences in the number of organisms added in the inocula. Thin-layer chromatography followed by autoradiography showed that the methionine incorporated into the organisms was still being metabolized to cysteine. Just before the sharp cut-off in methionine incorporation, e.g. at $\mathrm{I} 6 \mu \mathrm{g}$. $\mathrm{SeS}_{2}$, there was a gradual increase in the amount of methionine incorporated, but no increase in the yield of organisms. This accumulation of methionine may represent an attempt by the organisms to overcome the toxic effect of the inhibitor. The very few organisms that it was possible to harvest after the sharp cut-off, e.g. at $\mathrm{I} 7 \mu \mathrm{g}$. SeS $\mathrm{S}_{2}$, were markedly red in colour.

Selenium disulphide is prepared by fusing sulphur and selenium in the molecular proportions $2+\mathrm{I}$ although these two elements are miscible in all proportions. There is no evidence that any compound with the structure $\mathrm{SeS}_{2}$ is present in the final product (Matson, 1956); X-ray diffraction patterns show that some SeS is present and the rest of the material is present as solid solutions of elemental selenium and sulphur in the amorphous form. There are some sulphur rings-of- 8 , some selenium rings-of -8 and 
some mixed rings-of- 8 of the formula $\mathrm{Se}_{n} \mathrm{~S}_{m}$ where $n+m=8$. These are all stable lipid-soluble forms which are able to penetrate into the organisms (Horsfall, 1956).

Sulphur. Amorphous sulphur in the rings-of- 8 form was a very good inhibitor of the growth of Pityrosporum ovale although the cut-off in yield was not so sharp and occurred gradually over the range $35-50 \mu \mathrm{g}$. S/19.2 ml. medium.

Selenium. Previous work in this laboratory showed that a carefully prepared stable colloid of red selenium (Scandurra, Picani \& Cavallini, 1964) strongly inhibited the growth of Pityrosporum ovale. The red selenium described here did not inhibit growth at $1000 \mu \mathrm{g}$. $/ 19 \cdot 2 \mathrm{ml}$. medium; this observation is explained by non-penetration into the organisms of the black allotrope which was rapidly produced from the red allotrope in the medium.

Tellurium. Successful penetration of tellurium into Pityrosporum ovale was indicated by the black appearance of the organisms but no significant inhibition of growth occurred up to $1000 \mu \mathrm{g}$. $/ 19.2 \mathrm{ml}$. medium, confirming that tellurium is much less toxic to fungi than is sulphur (Hochster \& Quastel, 1963).

Seleno-urea. Seleno-urea inhibited the growth and uptake of $\left.{ }^{[35} \mathrm{S}\right] \mathrm{methionine}$ by Pityrosporum ovale in the same manner as selenium disulphide except that the cut-off was not so sharp, starting at about $20 \mu \mathrm{g}$. $/ 19 \cdot 2 \mathrm{ml}$. medium. Inhibited organisms were red, again showing the uptake of selenium. Seleno-urea is lipid-soluble, as are selenium disulphide, amorphous sulphur, red selenium and tellurium, and their mode of penetration into the organism is believed to be identical with that of other fungicides, i.e. simple diffusion through the lipoprotein cytoplasmic membranes, those with the highest lipid-water partition coefficient penetrating fastest (Albert, 1960).

\section{Table 2. Yields of Pityrosporum ovale and amounts of methionine and seleno-methionine incorporated}

$19.2 \mathrm{ml}$. shake culture of the standard medium with supplements indicated were incubated I week at $37^{\circ}$.

Sole sulphur source added to medium in $\mathrm{I} \cdot \mathrm{O} \mathrm{ml}$. solution

$$
\mu \text { moles incorporated into cells }
$$

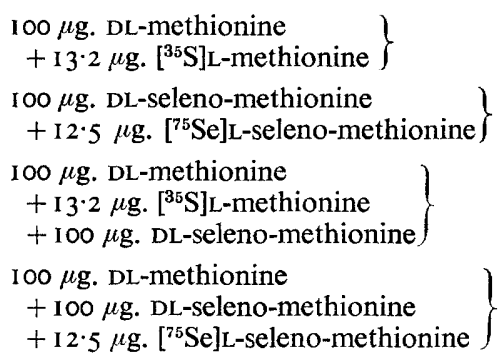

Amount of organism (mg. dry wt)

$$
\begin{aligned}
& 0.309 \text { methionine } \\
& 0.253 \text { seleno-methionine } \\
& 0.210 \text { methionine } \\
& 0.170 \text { seleno-methionine }
\end{aligned}
$$

Selenite. Selenite up to $760 \mu \mathrm{g}$. $\mathrm{SeO}_{2} / 19 \cdot 2 \mathrm{ml}$. medium did not inhibit the growth of Pityrosporum ovale nor the uptake of $\left.{ }^{35} \mathrm{~S}\right]$ methionine, which is consistent with the non-utilization of sulphate and sulphite for growth and the failure to incorporate $\left[{ }^{35} \mathrm{~S}\right]$ sulphate. Sulphite and selenite compete for specific sites on the cell membrane which are believed to form a complex with the substance before its active transport into the cell (Shrift, I96I); it is concluded that $P$. ovale lacks these specific active sites.

Seleno-methionine. Pityrosporum ovale grew satisfactorily on seleno-methionine as 
sole 'sulphur' source for I week (Table 2), the weight of organisms obtained being the same as for methionine. The amount of seleno-methionine incorporated into the organisms was slightly less than the amount of methionine; the incorporation of either was inhibited by the presence of the other and both were incorporated when present together. Methionine and seleno-methionine are known to behave as a competitive pair in a similar manner to sulphate/selenate and sulphite/selenite (Shrift, I96I). Some organisms have become adapted to growth on seleno-methionine, e.g. Chlorella vulgaris (Shrift \& Spoul, 1963), when selenium analogues of organic sulphur metabolites are used as substrates by the enzymes of the sulphur metabolites, and altered proteins are formed which function normally, except that organisms grown on seleno-methionine are larger and more dense, because of interference with cell division. A similar phenomenon probably occurred here with Pityrosporum ovale; cell division probably eventually ceased when sufficient cell-wall protein contained selenocystine instead of cystine. The effects of the inhibitors tested are summarized in Table 3.

Table 3. Effect of inhibitors on growth and metabolism of Pityrosporum ovale

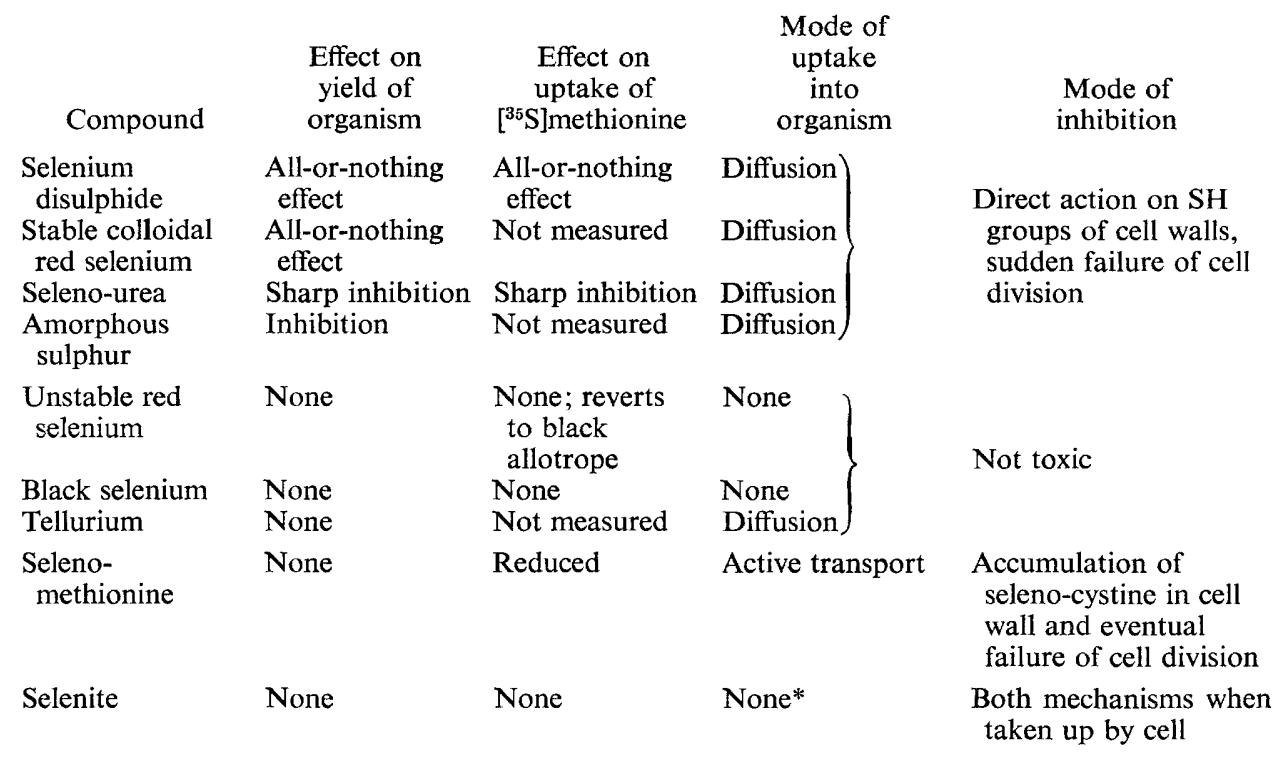

* Known to be by active transport in those organisms which incorporate selenite.

\section{DISCUSSION}

Accumulation of red amorphous selenium granules inside fungi (Rosenfeld \& Breath, 1964) and bacteria (Weiss, Ayres \& Kraft, 1965) growing on selenium compounds is a well-known phenomenon. For selenite the suggested mechanism is a spontaneous reaction with, for example, 32 molecules cysteine to form selenodicystine which decomposes to 16 molecules cystine and red $\mathrm{Se}_{8}$. For $\mathrm{S}_{8}$ (and $\mathrm{Se}_{8}$ ) which penetrate into the cell intact, Owens (1960) suggested ring fission to form $\mathrm{H}_{2} \mathrm{~S}$ and an $\mathrm{S}_{7}$ free radical which could undergo many possible reactions, e.g. combination with $2 \mathrm{SH}$ groups forming a sulphur bridge of the nature $\mathrm{R}-\mathrm{S}-(\mathrm{S})_{\mathrm{x}}-\mathrm{S}-\mathrm{R}$. 
Sulphydryl groups in the cell walls are important in cell division in yeasts (Nickerson \& van $\mathrm{Rij}$, 1949), protein disulphide reductase of the mitochondria controlling a local change of disulphide bonds to $\mathrm{SH}$ groups at the position of budding, so allowing the cytoplasm to 'balloon' out from the cell (Nickerson \& Falcone, 1954). Organic mercurial fungicides combine with the SH groups of the cell, especially of the cytoplasmic membrane, and an all-or-nothing effect results with the sudden failure of the semi-permeable membrane (Passow, Rothstein \& Clarkson, 1961). Failure of organisms to divide is another typical example of the operation of all-or-nothing effects, which are known to occur when a group of ligands acting in unison are essential for a particular cell function.

The fungitoxic effect of selenium disulphide, stable colloidal red selenium, amorphous sulphur and seleno-urea on Pityrosporum ovale is probably exerted by irreversibly changing the free SH groups of the cell wall into polysulphide bonds by the production of bridges, thus preventing cell division suddenly when enough such unions have been made. The eventual toxicity of seleno-methionine would be due to the production of seleno-cystine in the cell-wall proteins, which, when present in sufficient quantity, will stop cell division suddenly. Selenite appears to have a dual toxic function (in those organisms which can utilise sulphite), some selenium going through the normal pathway of sulphur metabolism to seleno-cystine and some forming red selenium and uniting $\mathrm{SH}$ groups.

\section{REFERENCES}

Albert, A. (1960). Selective Toxicity. London: Methuen.

BenhaM, R. W. (I94I). Cultural characteristics of Pityrosporum ovale, a lipophilic fungus. Nutrient and growth reauirements. Proc. Soc. exp. Biol. Med. 46, I76.

Benham, R. W. (1945). Pityrosporum ovale-a lipophilic fungus. Thiamin and oxalo-acetate as growth factors. Proc. Soc. exp. Biol. Med. 58, 199.

Crestfield, A. M., Moore, S. \& Stein, W. H. (1963). The preparation and enzymatic hydrolysis of reduced and S-carboxy-methylated proteins. J. biol. Chem. 238, 622

Eastoe, J. E. \& Courts, A. (1963). Practical Analytical Methods for Connective Tissue Proteins. London: Spon.

Hochster, R. M. \& Quastel, J. A. (1963). Metabolic Inhibitors. London and New York: Academic Press.

Holden, J. T. (1962). Transport and accumulation of amino acids in micro-organisms. In Amino Acid Pools. Ed. by J. T. Holden. Amsterdam: Elsevier.

Horsfall, J. G. (1956). Principles of Fungicidal Action. Waltham, Mass., U.S.A.: Chronica Botanica Co.

JAMES, A. T. \& Morris, L. J. (1964). New Biochemical Separations. London: Van Nostrand.

Margolis, D. \& Block, R. J. (1958). The sulphur metabolism of yeast. Contrib. Boyce Thompson Inst. 19, 437.

Matson, E. J. (I956). Selenium sulphide as an anti-dandruff agent. J. Soc. cosmet. Chem. 7, 459.

MAw, G. A. (I963). The uptake of some sulphur-containing amino acids by a Brewer's yeast. J. gen. Microbiol. 31, 247.

Nickerson, W. J. \& Falcone, G. (1954). The identification of protein disulphide reductase as a cellular division enzyme in yeasts. Science, N.Y. 124, 722.

Nickerson, W. J. \& VAN RIJ, N. J. W. (1949). The effect of sulphydryl compounds, penicillin and cobalt on the cell division mechanism of yeast. Biochim. biophys. Acta 3, $46 \mathrm{I}$.

Nordlander, B. W. (1929). U. S. Patent, 1,860,320.

OWENS, R. G. (1960). Effects of elemental sulphur, dithiocarbamates and related fungicides on organic acid metabolism. Develop. indust. Microbiol. I, 187.

Passow, H., Rothstein, A. \& Clarkson, T. W. (1961). The general pharmacology of heavy metals. Pharmacol. Rev. 13, 185. 
PASTERNAK, C. A. (1962). Sulphate activation and its control in Escherichia coli and Bacillus subtilis. Biochem. J. 85, 44.

Pigg, C. J., Spence, K. D. \& Parks, L. W. (1962). Methionine biosynthesis in yeast. Archs Biochem. Biophys. 97, 49I.

Postgate, J. R. (1963). The examination of sulphur auxotrophs: a warning. J. gen. Microbiol. 30, $48 \mathrm{r}$.

Rosenfeld, I. \& Breath, O. A. (1964). Selenium. London and New York: Academic Press.

Scandurra, R., Picani, G. \& Cavallini, D. (I964). Ossidazone di alcuni tioli catalizzata dal selenio colloidale. Giorn. Biochem. I3, 440.

Schultz, A. S. \& MCManus, D. K. (1950). Amino acids and inorganic sulphur as sulphur source for the growth of yeasts. Archs Biochem. 25, 40I.

Schultz, A. S., McManus, D. K. \& Pomber, S. (1949). Amino acids as carbon source for the growth of yeasts. Archs Biochem. 22, $4 \mathrm{I} 2$.

SHRIFT, A. (196I). Biochemical interrelations between selenium and sulphur in plants and microorganisms. Fedn Proc. Fedn Am. Socs exp. Biol. 20, 695.

Shrift, A. \& Spoul, M. (1963). The stable adaptation induced by selenomethionine in Chlorella vulgaris. Biochim. biophys. Acta 7r, 332.

Skerman, T. M. \& Singleton, R. J. (1964). Sulphur nutrition of two strains of the yeast, Debaromyces kloeckeri, isolated from sub-Antarctic soil. Can. J. Microbiol. ro, 397.

Spoor, H. J., Traub, E. T. \& Bell, M. (1954). Pityrosporum ovale types cultured from normal and seborrheic subjects. Archs Derm. Syph. Chicago 69, 323.

SWIFT, J. A. \& DUnbar, S. F. (1965). Ultra structure of Pityrosporum ovale and Pityrosporum canis. Nature, Lond. 296, 1174.

THORNE, N. (1963). Shampoos. Br. J. clin. Pract. 17, 357.

Treadwell, F. P. \& Hall, W. T. (1952). Analytical Chemistry, 9th ed. London: John Wiley.

Weiss, K. F., Ayres, J. C. \& Kraft, A. A. (1965). Inhibitory action of selenite on Escherichia coli, Proteus vulgaris and Salmonella thompson. J. Bact. 9o, 857.

Wood, J. L. \& Perkinson, S. D. (1952). Yeast biosynthesis of radioactive sulphur compounds. J. Am. chem. Soc. 74, 2444. 